\title{
The Efiect of Ascorbic Acid on Infection of Chick-Embryo Ciliated Tracheal Organ Cultures by Coronavirus
}

\author{
By \\ J. G. Atherton, C. C. Kratzing, and Anne Fisher \\ Departments of Microbiology and Physiology, University of Queensland, \\ Brisbane, Australia \\ With 1 Figure \\ Accepted August 10, 1977
}

\begin{abstract}
Summary
Chick embryo tracheal organ cultures showed increased resistance to infection by a coronavirus after exposure to ascorbate, while chick respiratory epithelium and allantois-on-shell preparations showed no increase in resistance to infection by an influenza virus or a paramyxovirus.
\end{abstract}

\section{Introduction}

Recently it was established that the mucoid surface-film of lung alveolae contains a very high concentration of ascorbic acid. While there are difficulties in determining the ascorbic acid content of the surface film, it was estimated to be between 1.0 and $3.5 \mathrm{mg} / \mathrm{ml}(16)$. Because it was thought that these concentrations may behave as a defensive barrier, systems using monolayer cultures of chickembryo respiratory epithelium, allantois-on-shell and chick-embryo ciliated tracheal organ (CETO) cultures were used to study the effect of ascorbic acid on virus infection. The viruses used were members of the Families Orthomyxoviridae (influenza A), Paramyxoviridae (Newcastle disease virus, NDV), and Coronaviridae (avian infectious bronchitis virus, IBV).

\section{Materials and Methods}

Respiratory epithelium cultures were prepared either in "Falcon" tissue culture flasks $(30 \mathrm{ml})$ or in "Linbro" 96 cup polystyrene tissue culture microplates IS-FB-96TC. Allantois-on-shell preparations were made by the method described by FAzkras and WHITE (6).

CETO cultures were prepared by the method of ChERRY and TAYLor-Robinson (4) with minor modifications. The trachea were dissected out from 20 day-old chickembryos and cut transversely into rings $1 \mathrm{~mm}$ thick. After washing, the rings were placed individually into tubes containing $3 \mathrm{ml}$ of Eagle's basal medium (BME) plus glutamine and antibiotics, buffered to $\mathrm{pH}$ 7.4. Full cilial activity could be observed 
microseopically for up to 21 days when these cultures were maintained at $37^{\circ} \mathrm{C}$, with medium changes twice weekly.

The influenza virus, human influenza virus Type A, strain V73-1826, was obtained from Commonwealth Serum Laboratories, Melbourne. The Paramyxovirus, Newcastle disease virus, strain V4-10 and the Coronavirus, avian infectious bronchitis virus, strain B-3125-1, were both isolated and identified by Mr. G. Simmons of the Animal Research Institute, Brisbane.

Influenza virus and Newcastle disease virus titrations were performed either in micro-cultures of chick respiratory epithelium or in allantois-on-shell preparations, by inoculating 8 replicate eups with dilutions of virus made in half-log steps, then incubating the preparations for 2 days at $37^{\circ} \mathrm{C}$ in a humidified chamber. Growth of virus was detected by testing for haemagglutinin by the addition of $0.25 \mathrm{ml}$ of a 5 per cent suspension of washed adult fowl red blood cells, after which the plates were incubated at $4^{\circ} \mathrm{C}$ for 1 hour and then read for haemagglutinin using substage indirect lighting. Virus end-points were then calculated as ID $\mathrm{D}_{50} / \mathrm{ml}$ by the REED-MUENCH method (12).

Titrations of avian infectious bronchitis virus were performed by inoculating 4. replicate chick-embryo tracheal organ culture tubes previously selected for cilial activity, with dilutions of virus made in half-log steps, then continuing to incubate the preparations on a roller drum at $15 \mathrm{rev} / \mathrm{hour}$ at $37^{\circ} \mathrm{C}$. These tubes were observed daily for cilial activity. Cilial activity was arbitrarialy graded from $4+$ to 0 . The final observation was made after 4 days incubation and cilial activity reduced to $1+$ or less taken as evidence of virus infection. Virus end-points were then calculated as CETO $\mathrm{TD}_{50} / \mathrm{ml}$ by the Reed-Muench method.

Ascorbic acid was estimated by the method of Bolns and Book (2). All ascorbic acid solutions were used in neutralized form, without the addition of glutathione.

The uptake of ascorbic acid by cells was measured by exposing CETO cultures, chick-embryo respiratory epithelial cultures and allantois-on-shell preparations respectively to ascorbic acid in concentrations of $15-10,000 \mu \mathrm{g} / \mathrm{ml}$ for 2 hours at $37^{\circ} \mathrm{C}$. Samples of the cells were then taken for ascorbic acid determination and the remainder used in viral infectivity tests. Tissue ascorbate concentrations obtained in CE respiratory epithelium and allantois-on-shell, were comparable with those of CETO (Table 1).

Cell culture medium to be tested for interferon was frozen and thawed once from $-20^{\circ} \mathrm{C}$, adjusted to $\mathrm{pH} 2.2$ with $1 \mathrm{M} \mathrm{HCl}$, stored at $4^{\circ} \mathrm{C}$ for 24 hours, brought to $\mathrm{pH} 7.2$, and then centrifuged at $100,000 \times g$ for 1 hour. The supernatant was stored at $4^{\circ} \mathrm{C}$ and tested for interferon activity within 48 hours. All interferon titrations were performed against a standard preparation made by similar treatment of tissue culture supernatant from NDV-infected chick embryo respiratory epithelial cell cultures. Interferon titres were determined using a 50 per cent plaque reduction method similar to that described by Moenrmag et al. (10) using West Nile virus in primary ehickembryo fibroblast monolayers. Virus nomenclature used is that of Fenner (7).

\section{Results}

Three types of experiments were done:

1. Ascorbic acid in concentrations from 15 to $10,000 \mu \mathrm{g} / \mathrm{ml}$ was incubated with standard virus suspensions diluted in BME for from 1 to 3 hours at $37^{\circ} \mathrm{C}$. A second series was held at $4^{\circ} \mathrm{C}$. Results of infectivity assays were plotted graphically and compared with those from virus suspensions made in BME alone. No significant effect of ascorbic acid on the rate of thermal inactivation of influenza virus, NDV or IB virus was observed.

2. In the second type of experiment virus and ascorbie acid were added to cells at the same time and the ascorbate maintained throughout incubation. Five dilution series of each virus were made at $4^{\circ} \mathrm{C}$, one in BME alone and the others in ascorbic acid dilutions of $15,300,1800$ and $10,000 \mu \mathrm{g} / \mathrm{ml}$. Each dilution 
series was then used to perform virus infectivity titrations in the cell system appropriate for the virus under test. No significant effect on viral infectivity was observed.

3. In the third type of experiment, cells were exposed to ascorbic acid in concentrations of $15-10,000 \mu \mathrm{g} / \mathrm{ml}$ for 2 hours at $37^{\circ} \mathrm{C}$. Samples of cells were taken for determination of ascorbic acid content and the remainder used in viral infectivity tests. Simultaneous parallel virus titrations were performed on cells which had not been exposed to ascorbic acid.

The resistance of cells to infection was measured by exposing them to halflog dilutions of a standard virus suspension, incubating, and then ealculating the virus infectivity end-point.

A lower titre for virus infectivity end-point in treated cells compared with untreated cells, indicating a decrease in plating efficiency, was taken as evidence of increased resistance of the treated cells to virus infection.

Increasing cell content of ascorbic acid did not increase the resistance of cells to infection by influenza or Newcastle disease viruses. However resistance of CETO cultures to TB virus infection rose with increasing ascorbic acid content (Table 1 and Fig. 1). Tissue containing $10^{3.6} \mu \mathrm{g} / \mathrm{ml}(3980 \mu \mathrm{g} / \mathrm{ml})$ of ascorbate showed a virus infectivity end-point of $10^{2.5} \mathrm{CETO}^{\mathrm{ID}} \mathrm{D}_{50} / \mathrm{ml}$ compared with 103.7 CETO ID $50 / \mathrm{ml}$ for tissues without ascorbate, i.e. a 15.8 times larger dose was needed to infect tissues containing ascorbate, with IB virus.

Reports of induction of increased serum concentrations of interferon in vivo by ascorbate $(8,11,14,15)$ prompted tests for interferon in the experiments cited. CETO cultures were treated with $10,000 \mu \mathrm{g} / \mathrm{ml}$ of ascorbate for 2 hours, then infected with IB virus dilutions from $10^{2}-10^{4.5}$ CETO ID $50 / \mathrm{ml}$ for 72 hours at

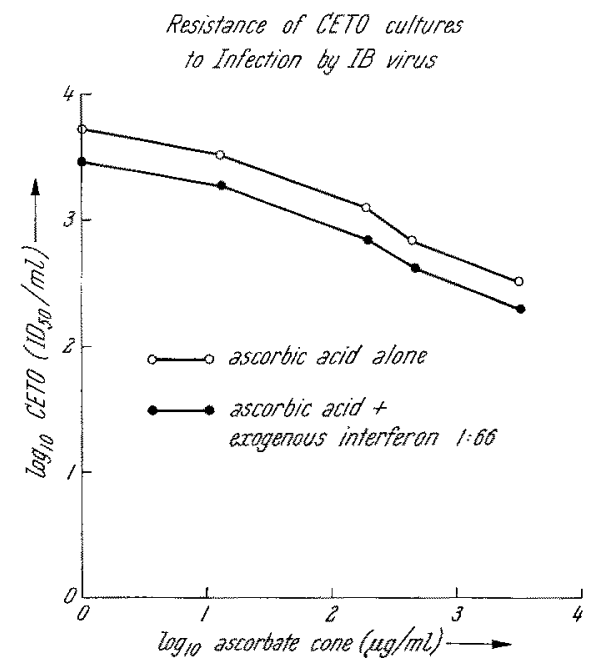

Fig. 1. The infectivity end-points of a standard preparation of Coronavirus (IBV) were determined in tissues containing increasing amounts of ascorbic acid $\circ-0$ Tissue containing $10^{3.6} \mu \mathrm{g} / \mathrm{ml}$ ascorbic acid required 15.8 times the virus to produce infection compared to tissues without ascorbate. After cells had been pretreated with exogenous interferon the virus dose necessary to cause infection was approximately 
$37^{\circ} \mathrm{C}$. The fluids were then assayed for interferon by a plaque-reduction test using West Nile virus in chick-embryo fibroblast monolayers. No significant differences in interferon content could be detected between fluid from cells alone, cells plus ascorbate, and virus-infected cells with and without ascorbate.

Standard interferon prepared as described above had a 50 per cent plaque reduction $\left(\mathrm{PR}_{50}\right)$ titre of $1: 132$. The effect of interferon-plus ascorbic acid was tested by adding an interferon preparation diluted $1: 66$ (twice the $\mathrm{PR}_{50}$ concentration) to CETO cultures exposed to varying ascorbic acid coneentrations and incubating at $37^{\circ} \mathrm{C}$ for 2 hours. These CETO cultures were then infected with $10^{3.7} \mathrm{CETO} \mathrm{ID}_{50} / \mathrm{ml} \mathrm{IB}$ virus and the infectivity end-points determined. The results are shown in Table 1 and Figure 1.

Differences between mean titres obtained with and without interferon in the presence of ascorbate, although little greater than the s.e., suggest that interferon exerted a slight effect, i.e. about doubling cell resistance to virus. This effect is very small compared with that of ascorbate.

Table 1. Resistance of CETO cultures to infection by $I B$ virus in the presence of ascorbic acid with and without exogenous interferon

\begin{tabular}{lll}
\hline $\begin{array}{l}\text { Pretreatment of cells } \\
2 \text { hours } 37^{\circ} \mathrm{C}\end{array}$ & $\begin{array}{l}\text { Tissue conc. of } \\
\text { ascorbate reached } \\
\log _{10} \mu \mathrm{g} / \mathrm{g}\end{array}$ & $\begin{array}{l}\text { Virus titre } \\
\log _{10} \text { CETO ID } 0 / \mathrm{ml} \\
\text { mean stand. error }\end{array}$ \\
\hline None & Nil & $3.7 \pm 0.21$ \\
\hline Ascorbate & & \\
$15 \mu \mathrm{g} / \mathrm{ml}$ & 1.14 & $3.5 \pm 0.20$ \\
$300 \mu \mathrm{g} / \mathrm{ml}$ & 2.29 & $3.1 \pm 0.18$ \\
$1,000 \mu \mathrm{g} / \mathrm{ml}$ & 2.66 & $2.8 \pm 0.18$ \\
$10,000 \mu \mathrm{g} / \mathrm{ml}$ & 3.59 & $2.5 \pm 0.19$ \\
\hline Interferon $1: 66$ & $\mathrm{Nil}$ & $3.3 \pm 0.20$ \\
\hline Interferon $1: 66+$ Ascorbate & & \\
$15 \mu \mathrm{g} / \mathrm{ml}$ & 1.14 & $3.2 \pm 0.19$ \\
$300 \mu \mathrm{g} / \mathrm{ml}$ & 2.29 & $2.9 \pm 0.19$ \\
$1,000 \mu \mathrm{g} / \mathrm{ml}$ & 2.66 & $2.6 \pm 0.17$ \\
$10,000 \mu \mathrm{g} / \mathrm{ml}$ & 3.59 & $2.3 \pm 0.17$ \\
\hline
\end{tabular}

\section{Diseussion}

SchWERDT and SchwerdT (14) showed that exposure of WI-38 cells to ascorbic acid plus glutathione mixtures for 2 days prior to infection with rhinovirus suppressed multicyclic but not single cycle growth. The same authors found some evidence for barely detectable levels of interferon at high virus MOI.

MURPHy el al. (11) found that increased amounts of ascorbate were unable to prevent parainfluenza virus 3 experimental infection or primary immune response in cotton-topped marmosets. However the onset of disease was delayed, clinical responses reduced and mortality decreased in animals fed doses of ascorbic acid equivalent to $35 \mathrm{~g} /$ day for man. On the other hand, ScHwaRtz et al. (13) followed a number of parameters of virus infection and disease in a group of human volunteers infected with rhinovirus 44 , but were unable to show any differences between controls and those treated with ascorbic acid. 
Our results show that ascorbic acid exerted no direct effect on the infectivity of any of the three viruses tested, nor did it affect the resistance of cells to infection by the Orthomyxovirus (influenza) or the Paramyxovirus (NDV). However CETO cultures previously exposed to ascorbic acid exhibited considerably increased resistance to infection by Coronavirus (IBV). These results suggest that different mechanisms operate for infection of cells by viruses of these different groups.

The different effects of ascorbate on experimental infection by viruses from different groups suggest that, when clinical trials of the effect of ascorbate on respiratory virus infection are conducted $(1,3,5,9)$ it is important to ascertain to which group the infecting virus belongs.

\section{References}

1. Anderson, T. W., Beaton, G. G., Corey, P., Spero, L. : Winter illness and vitamin C: The effect of relatively low dose. Canad. Med. Assoc. J. 112, $823-826$ (1975).

2. Borrn, D. W., Boor, L.: Oxidation of ascorbic acid to dehydroascorbic acid. Science 106, 451 (1947).

3. Chatmers, T. C.: Effects of ascorbic acid on the common cold: An evaluation of the evidence. Amer. J. Med. 58, 532-536 (1975).

4. Cherry, J. D., Taylor-Robinson, D.: Large-quantity production of chicken embryo tracheal organ cultures and use in viral and mycoplasma studies. Appl. Microbiol. 19, 658-662(1970).

5. Drkes, M. H., Meter, P.: Ascorbic acid and the common cold: Evaluation of its efficacy and toxicity. J. Amer. Med. Assoc. 231, 1073-1079 (1975).

6. Fazekas, de St. Groth, S., White, D. O.: An improved assay for the infectivity of influenza viruses. J. Hyg. 56, 151-163 (1958).

7. Fenner, F.: Classification and nomenclature of viruses. Second Report of the International Committee on Taxonomy of Viruses. Intervirology 7, 4-115 (1976).

8. Geber, W. F., LeFkowitz, S. S., HUNG, C. Y.: Effect of ascorbic acid, sodium salicylate and caffeine on the serum interferon level in response to viral infection. Pharmacology 13, 228-233 (1975).

9. Karlowski, T. R., Chalmers, T. C., Frenkel, L. D., Kapikian, A. Z., Lewis, T. L., LYNCH, J. M.: Ascorbic acid for the common cold: A prophylactic and therapeutic trial. J. Amer. Med. Assoc. 231, 1038 - 1042 (1975).

10. Momining, J. M., Strinebring, W. R., Merchant, D. J.: Survey of interferon production and sensitivity in human cell lines. Appl. Microbiol, 22, 102-105 (1971).

11. Murphy, B. L., Krushak, D. H., Maynard, J. E., Bradley, D. W.: Ascorbic acid (vitamin $C$ ) and its effects on parainfluenza type 3 virus infection in cottontopped marmosets. Lab. Anim. Sci. 24, 229-232 (1974).

12. REed, L. J., Muench, H. : A simple method of estimating fifty per cent end-points. Amer. J. Hygiene 27, 493-497 (1938).

13. Sohwartz, A. R., Togo, Y., Hornick, R. B., Tominaga, S., Gleckman, R. A.: Evaluation of the efficacy of ascorbic acid in prophylaxis of induced rhinovirus 44 infection in man. J. inf. Dis. 128, 500-505 (1973).

14. Schwerdt, P. R., Schwerdt, C. E. : Effect of ascorbic acid on rhinovirus replication in W 1-38 cells. Prof. Soc. exp. Biol. Med. 148, 1237-1243 (1975).

15. SIEGEL, B. V.: Enhanced interferon response to murine leukemia virus by ascorbic acid. Infect. Immun. 10, 409-410 (1974).

16. Wirms, R. J., Kratzing, C. C.: Ascorbic acid in rat lung. Biochem. biophys. Res. Comm. 59, 1250-1253 (1974).

Authors' address: Dr. J. G. AтнkRTon, Department of Microbiology, University of Queensland, St. Lucia, Brisbane 4067, Australia. 